\title{
Integration of peach (Prunus persica L) biochar, compost and peach residues along with beneficial microbes and phosphorus improve agronomic efficiency, phosphorus use efficiency, partial factor productivity and soil $P$ in soybean vs maize crops
}

\author{
Imran Imran * and Amanullah Amanullah \\ Department of Agronomy, the University of Agriculture Peshawar, Pakistan \\ *Corresponding author: imranagrarian@aup.edu.pk
}

\begin{abstract}
Phosphorus $(\mathrm{P})$ is an important element in a complete and balanced fertility program that can improve crop P use efficiency and ultimately productivity and profitability. Phosphatic fertilizers use without organic fertilizers leads to gradual decline in soil organic matter, native nutrient status and ultimately reduction in agricultural productivity and economic growth. The objectives of this was to evaluate $\mathrm{P}$ efficiencies with incorporation of peach sources, beneficial microbes and P application. From sustainability points of view, alternative use of different sources and forms of organic sources alone or in combination with inorganic $\mathrm{P}$ and beneficial microbes possess potential for improving productive capacity of the soil. Separate field experiments (one each on maize and soybean as a test crop) were conducted at Agriculture Research Institute Mingora Swat (ARI) for two consecutive years in summer season of 2016 (year one) and 2017 (year two). For the first time such a study were conducted to utilize peach leftovers and biomass (leaves, twigs, fruits, stones and barks partially decomposed, its compost and biochar) along with three phosphorus (P) levels (50, 75, $100 \mathrm{~kg} \mathrm{P} \mathrm{ha}^{-1}$ ) and two beneficial microbes (PSB and Trichoderma) on such a way to enhance soil sustainability and P use efficiency of soybean and maize. The results revealed that organic sources had significant effect on soybean and maize $\mathrm{P}$ use efficiency (PUE), P agronomic efficiency (PAE), partial factor productivity (PFPp) and soil P concentration. In experiment 1 among the organic sources, peach residues increased soil P (12.0 $\left.\mathrm{mg} \mathrm{kg}^{-1}\right)$ as compared to peach compost and biochar $\left(8.6 \& 11.7 \mathrm{mg} \mathrm{kg}^{-1}\right)$. Soil $\mathrm{P}$ concentration was maximum $\left(12.1 \mathrm{mg} \mathrm{kg}^{-1}\right)$ with PSB than Trichoderma $\left(9.5 \mathrm{mg} \mathrm{kg}^{-1}\right)$. Application of $\mathrm{P}$ at 100 $\mathrm{kg} \mathrm{ha}^{-1}$ increased soil P contents $\left(16.9 \mathrm{mg} \mathrm{kg}^{-1}\right)$ as compared to 50 and $75 \mathrm{~kg} \mathrm{P} \mathrm{ha}^{-1}(5.9 \& 9.6 \mathrm{mg}$ $\left.\mathrm{kg}^{-1}\right)$ respectively. $\mathrm{P}$ concentration was increased drastically in year $2\left(12.4 \mathrm{mg} \mathrm{kg}^{-1}\right)$ than year one $\left(9.1 \mathrm{mg} \mathrm{kg}^{-1}\right)$. PUE in both crops (soybean and maize) was maximum (25.6 \& $\left.28.4 \%\right)$ with peach biochar than compost and residues along with Trichoderma ( $21.7 \& 27.8 \%)$. Highest PUE in soybean was recorded with $75 \mathrm{~kg} \mathrm{P} \mathrm{ha}^{-1}(22.2 \%)$ however in maize maximum PUE was noted with $50 \mathrm{~kg} \mathrm{P}^{-1}(33.5 \%)$. PAE and PFPp in both crops was maximum with biochar and soil application of Trichoderma than other organic sources and PSB. Among the P levels highest PAE in soybean and maize was recorded with $75 \mathrm{~kg} \mathrm{ha}^{-1}$ whereas PFPp in soybean was maximum with $75 \mathrm{~kg} \mathrm{P} \mathrm{ha}^{-1}$ and interestingly in maize it was noted with $50 \mathrm{~kg} \mathrm{ha}^{-1}$. Conclusively soybean and maize PAE, PFPp and PUE was higher with biochar, soil incorporation of Trichoderma and $\mathrm{P}$ at the rate of $75 \mathrm{~kg} \mathrm{ha}^{-1}$ and can improve soybean and maize yield and soil productivity on sustainable basis.
\end{abstract}

Keywords: Peach carbon sources; agronomic efficiency; PUE; partial factor productivity; soil P; biochar; Trichoderma; PSB. 


\section{Introduction}

Higher organic matter and soil carbon serves many important functions towards soil health and maximum crop productivity. (Imran et al., 2018). Organic matter is a reservoir of nutrients decomposed by soil microorganism mineralized and released in to the soil for plant use. Each percent of organic matter in the soil requires about 25 pounds of $\mathrm{N}, 5$ pounds of $\mathrm{P}_{2} \mathrm{O}_{5}$, and 3 pounds of sulfur which can significantly reduce the use of fertilizers. Organic matter comes from plant residue and roots that have been broken down and decomposed (Arif et al., 2017). Only about 10 percent of organic material is converted to stable organic matter, so it takes a lot of plant residue, roots and time to increase the amount in the soil significantly. In high organic matter level soils this can lead to significant fertilizer savings (Imran, 2018). When soil temperature is high more nutrients are released and benefiting summer crops more than winter crops. Organic matter increases the water holding capacity of the soil to the extent of 90 percent of its weight. Particularly in drier climates where soil moisture is almost limiting factor can enhance crop yield with organic matter supplementation. Further high organic matter soils have a higher percentage of stable soil aggregates which don't break down, consolidate or condense when it rains (Arif et al., 2017; Imran et al., 2018). Increasing the pore space in the soil and in turn taking in more water in addition to decreasing runoff and erosion. It takes years to see a significant improvement, but there are ways that we can increase organic matter levels in the soil (Imran et al., 2017). Yuan and Xu, (2011) and Lentz and Ippolito (2012) stated that integrated P management is essential for the improvement of soil health, crop growth, seed yield and nodulations in legumes and human health (Mukherjee and Zimmerman, 2013).

Plant residues, compost and biochar significantly improve soil organic matter and sustain soil health and crop productivity (Imran et al., 2017). The peach (Prunus persica L.) is a deciduous tree (Khan et al., 2008; Xiang et al., 2012) having highest fall, left overs and post-harvest losses and possesses high nutritional value for crop as a sources of organic supplements. To manage peach drop and post-harvest waste along with leaves, twigs and barks on a proper way should be used as organic matter and nutrients supplements in the form of biochar, compost and dry based residues. In Pakistan district Swat is the largest producer of peaches and large part of this valuable crop is lost as a drop-off and at post-harvest stage. It is estimated that the loss of $46 \%$ on average for different varieties taken as a whole; the range being $18 \%$ to $61 \%$ (Khan et al., 2008; Jones and Healey, 2010; Ye et al., 2014). No study is reported on peaches waste management and post-harvest losses relative to management of soil health and crop productivity in Pakistan. Managing peaches wastes for compost, biochar and dry based application as organic sources together with beneficial microbes and phosphorus application is an economic, integrated and environmental friendly approach towards increasing soil health and sustainable crop production.

In the present study, the impact of peach organic sources together with beneficial microbes and phosphorus was evaluated on growth and productivity of soybean and maize. Organic sources were included partially dry based, compost and biochar and their effect on soil health, P use efficiencies were evaluated in term of crop production and soil health.

\section{MATERIALS AND METHODS}

Consecutive two years field experiments were conducted at ARI Swat in summer seasons 2016 (year one) and 2017 (year two) one each on soybean (cv. Malakand-96) and maize (cv. Azam) to find out the impact of peach (Prunus persica L.) residues (leaves \& fruits having no stones, not decomposed) its compost comprised on composted leaves \& fruits having no stones and well decomposed and its biochar (peach tree stem, with peach stones, leaves and twigs), phosphorus levels and beneficial microbes on soil health, crop productivity and P use efficiencies of soybean, maize. The experiments were laid out in randomized complete block design having three 
replications. One control treatment (no P, no beneficial microbes and no organic sources applied) as check was also included in each replication of each experiment (soybean \& maize). The organic sources were applied one month before sowing. Peach residues for compost and biochar preparation were collected from Matta Tehsil, Village Sambat Cham, Chalghazy swat having Latitude (34 $\left.94^{\circ} 85.41\right)$ and Longitude (72 $\left.43^{\prime} 91.76\right)$. Peach bark, leaves and twigs were collected in the month of January and February (winter season) after pruning of peach orchards. Leaves and fruit stones were collected in fall season. Peach residues of early maturing cultivars (Early Grand, spring crest and A-69) were used in residues, compost and biochar preparation. The required P levels and beneficial microbes were applied at sowing time. Source of $\mathrm{P}$ was used single super phosphate (SSP) $18(\%)$, although sufure percentage was $12(\%)$. Basal dose of $\mathrm{N}$ (urea) $\left(25 \mathrm{~kg} \mathrm{ha}^{-1}\right)$ was applied to soybean crop at the time of sowing. The field was ploughed twice up to the depth of $20 \mathrm{~cm}$ with the help of cultivator, followed by planking. The plot size was kept $4 \mathrm{~m}$ in length and $2.7 \mathrm{~m}$ in width (10.8 $\mathrm{m}^{2}$ ) with row to row distance $45 \mathrm{~cm}$ apart and P-P distance $5 \mathrm{~cm}$ were maintained for soybean whereas the plot size of $4 \mathrm{~m}$ in length and $4.2 \mathrm{~m}$ in width $\left(16.8 \mathrm{~m}^{2}\right)$ was used with R-R distance $70 \mathrm{~cm}$ apart and P-P $25 \mathrm{~cm}$ for maize. Soybean (cv. Malakand-96) was sown at the rate of $100 \mathrm{~kg} \mathrm{ha}^{-1}$ on July $4^{\text {th }}$ 2016 and July $2^{\text {nd }} 2017$ and maize (cv. Azam) was sown at the seed rate of $30 \mathrm{~kg} \mathrm{ha}^{-1}$ on July $4^{\text {th }} 2016$ and July $2^{\text {nd }}$ 2017. Phosphate solubilizing bacteria (PSB) obtained from ARI Swat was inoculated with soybean and maize seed at the time of sowing whereas Trichoderma was applied in to the soil in each plot at the rate of 4 gram per plot $\left(10.8 \mathrm{~m}^{2}\right)$ at the time of sowing. Both PSB and Trichoderma were obtained from Agriculture Research Institute Mingora Swat. Irrigation schedule for soybean and maize was continued during both years and $1^{\text {st }}$ irrigation to soybean was done after emergence on $18^{\text {th }}$ July 2016 and $15^{\text {th }}$ July 2017, respectively, followed by next irrigation on $27^{\text {th }}$ August in, 2016, at pods formation stage and $3^{\text {rd }}$ August, 2017 at branches initiation stage. Rainfall was much higher in August 2016 as compared to August 2017. Only one irrigation was done in August, 2016 as compared to 2017 (two irrigations). Next irrigation was done on $9^{\text {th }}$ September at pods formation stage followed with irrigation on $17^{\text {th }}$ September 2016, at pods filling stage. In 2017, $3^{\text {rd }}$ irrigation was done on $31^{\text {st }}$ August at pods formation stage. Irrigation frequency was varied with rainfall and noted 5 irrigation for soybean crop till maturity in year one experiment (2016) while 4 irrigations were applied in year two experiment of 2017 (Table 1). Likewise, first irrigation to maize was done after emergence on $14^{\text {th }}$ July in 2016 and $11^{\text {th }}$ July in 2017. Second irrigations was applied on $2^{\text {nd }}$ August 2016, while in year two, irrigation was done on $5^{\text {th }}$ August 2017 at $6^{\text {th }}$ leaf stage. Rainfall was much higher in the month of August, 2016 as compared to August, 2017. In $2^{\text {nd }}$ year, next irrigation was done on 27th August 2017.

After emergence the maize crop was damaged by seedling borer (Busseola fusca and Chilo Partellus) and chemically preventive measures were taken with "Chloropyrifos 40 EC" (larsbeen) at the rate of $3 \mathrm{ml} \mathrm{L}^{-1}$ for seedling borer control. Weather data and treatment combination, compost and biochar preparation were same. Meteorological data for both experiments (soybean and maize) was recorded during growing periods of 2016 and 2017.

\section{Compost and biochar preparation}

Five trenches of 1 meter in width and 1 meter in depth while four meter in length were excavated in 2016 and 2017 respectively. Peach dried leaves of $20 \mathrm{~cm}$ pile were added at the bottom of the trench followed by wasted peach fruits, twigs and other peach residues $(20 \mathrm{~cm})$ and repeated each pile layer up to the top of the trench and covered with soil. A thin layer of soil was spread on each layer of peach residues (leaves, fruits). No beneficial microbes were applied to enhance composting process. After compost preparation, the trenches were opened and collected compost in bags and conveyed to experimental site. Collected dry leaves of peach, barks, twigs and fruit stone were placed in the small metal barrel for biochar preparation through pyrolysis. Small holes were made at base of barrel to remove ashes and providing continues limited air to avoid choking of the pyrolysis. After all the peach residues and woods converted to biochar, then biochar was collected and stored at room temperature until use. The process was repeated several times to get $600 \mathrm{~kg}$ of biochar (at the rate of 
$10 \mathrm{t} \mathrm{ha}^{-1}$ ) for both experiments on soybean (experiment \#1) and maize (experiment \# 2) in the two years.

\section{Soil and plant analysis}

The analyzed data (Table 1) revealed that the soil was acidic in nature and P deficient of both crops. For both years study (2016 and 2017) soil analysis (Pre and Post-Harvest soil analysis) for $\mathrm{pH}$, soil texture, soil organic matter, soil carbon, lime (\%), Total Nitrogen and Extractible $\mathrm{P}$ and $\mathrm{K}$ (Table 1) was evaluated (Laird et al., 2010) at the Soil and Water testing Laboratory of the Agriculture Research Institute Mingora Swat, following the standard procedures as described by US Salinity Lab. Staff (1954). After harvest of soybean and maize the soil was analyzed and noted that organic matter, $\mathrm{N}, \mathrm{P}$ and $\mathrm{K}$ was increased tremendously with application of peach sources, beneficial microbes and P.

\section{Phosphorus fertilizer use efficiency (PUE)}

The phosphorus fertilizer use efficiency for both crops (soybean and maize) was calculated for each sub plot as follow (Gourley et al., 1993);

$$
\mathrm{PUE}=\frac{\mathrm{P} \text { uptake in ferilized plots }\left(\mathrm{kg} \mathrm{ha}^{-1}\right)-\mathrm{P} \text { uptake in control plots }\left(\mathrm{kg} \mathrm{ha}^{-1}\right)}{\mathrm{P}} \times 100
$$

Agronomic Efficiency $\left(\mathrm{kg} \mathrm{kg}^{-1}\right)$

Agronomic efficiency for both crops (soybean and maize) was worked out by using the following procedure of Mengel and Kirkby, (2001):

$$
\text { Ag } \mathrm{E}=\frac{\text { Yield } \mathrm{F}-\text { Yield C }}{\text { Fertilizer P applied }}
$$

Where F is plots treated with phosphorus fertilizer while $\mathrm{C}$ is control plot, while $\mathrm{P}$ stands for phosphorus applied.

\section{Partial factor productivity}

Phosphorus PFP for both crops (soybean and maize) was worked out by using the following procedure of Mengel and Kirkby, (2001);

$$
\mathrm{PFP}=\frac{\text { Seed yied }\left(\mathrm{kg} \mathrm{ha}^{-1}\right)}{\text { rate of } \mathrm{P} \text { applied }\left(\mathrm{kg} \mathrm{ha}^{-1}\right)}
$$

\section{Statistical analysis}

Data was statistically analyzed according to Steel et al. (1996) and means was compared using LSD test $(\mathrm{P} \leq 0.05)$.

\begin{tabular}{|c|c|c|c|c|c|}
\hline \multirow{2}{*}{ Soil property } & \multirow{2}{*}{ Unit } & \multicolumn{2}{|c|}{ Before sowing soybean } & \multicolumn{2}{|c|}{ Before sowing maize } \\
\hline & & 2016 & 2017 & 2016 & 2017 \\
\hline
\end{tabular}

Table 1. Physico-chemical analysis of soil before sowing of soybean and maize in 2016 (year one) and 2017 (year two). 


\begin{tabular}{cccccc}
\hline Clay & $\%$ & 11.6 & 11.6 & 9.6 & 9.6 \\
Silt & $\%$ & 50 & 50 & 56 & 56 \\
Sand & $\%$ & 38.4 & 38.4 & 34.4 & 34.4 \\
Textural Class & - & Silt loam & Silt loam & Silt loam & Silt loam \\
pH (1:5) & - & 5.8 & 6 & 6.2 & 5.9 \\
Organic Matter & $\%$ & 1.38 & 1.76 & 1.86 & 2.64 \\
Lime content & $\%$ & 4 & 4.8 & 10.3 & 11.2 \\
Total Nitrogen & $\%$ & 0.07 & 0.16 & 0.09 & 0.11 \\
AB-DTPA extract. P $(\mathrm{ppm})$ & $\mathrm{mg} \mathrm{kg}^{-1}$ & 6.1 & 6.3 & 5.7 & 6.2 \\
AB-DTPA extract. K $(\mathrm{ppm})$ & $\mathrm{mg} \mathrm{kg}^{-1}$ & 76 & 89 & 90 & 112 \\
\hline
\end{tabular}

Reference value: clay (heavy), Silt (medium), Sand (light), $\mathrm{pH}$ (acidic $<7$, neutral $=7$, alkaline $>7$ ), Organic matter (low $<0.86$, medium 0.86-1.29, high $>1.29$ ), Lime content (slightly calcarious $<3$, moderately cal 3-15, strongly cal $>15$ ), Total nitrogen (low $<0.1$, medium 0.1-0.5, adequate $>0.5$ ), ABDTPA extract. P (ppm) (low $<3$, medium 4-7, adequate $>7$ ), AB-DTPA extract. K (ppm) (low $<60$, medium 60-120, adequate $>120)$.

\section{Results and discussions}

\section{Soil P content after harvest of soybean and maize crops}

Planned mean comparison emphasises that rest plot ensured highest $\mathrm{P}$ content $\left(10.8 \mathrm{mg} \mathrm{kg}^{-1}\right)$ as compared to control (5.3 $\mathrm{mg} \mathrm{kg}^{-1}$ ) (Table 2). All the organic sources had significant effect on soil $\mathrm{P}$ content and maximum at par value soil $\mathrm{P}$ content $\left(12.0 \mathrm{mg} \mathrm{kg}^{-1}\right)$ was noted with peach residues and biochar amendments $\left(11.7 \mathrm{mg} \mathrm{kg}^{-1}\right)$ while relatively slightest $\mathrm{P}$ content $\left(8.6 \mathrm{mg} \mathrm{kg}^{-1}\right)$ was recorded with compost application. In soil under maize crop, P content in rest plot were thoroughgoing (13.8 $\mathrm{mg} \mathrm{kg}^{-1}$ ) as compared to control (5.8 $\left.\mathrm{mg} \mathrm{kg}^{-1}\right)$ (Table 2, Figure 1). All the organic sources make sure significant effect on soil $\mathrm{P}$ content and maximum $\mathrm{P}$ content $\left(15.8 \mathrm{mg} \mathrm{kg}^{-1}\right)$ was noted with biochar amendments followed by peach compost $\left(14.1 \mathrm{mg} \mathrm{kg}^{-1}\right)$ while relatively minimum P content $(11.6 \mathrm{mg}$ $\mathrm{kg}^{-1}$ ) was recorded with peach residues incorporation. Beneficial microbes had also ameliorating effect on P content and highest $\mathrm{P}$ contents $\left(12.1 \mathrm{mg} \mathrm{kg}^{-1}\right)$ was noted in soybean soil with PSB inoculation as compared to soil application of Trichoderma $\left(9.5 \mathrm{mg} \mathrm{kg}^{-1}\right)$. Similarly in maize plots maximum $\mathrm{P}$ content (15.1 mg kg-1) was found with seed inoculation with PSB than that soil application of Trichoderma (12.5 $\left.\mathrm{mg} \mathrm{kg}^{-1}\right)$. Phosphorus application increased soil $\mathrm{P}$ contents and high concentration of $\mathrm{P}$ in soybean soil $\left(16.9 \mathrm{mg} \mathrm{kg}^{-1}\right)$ was recorded with $100 \mathrm{~kg} \mathrm{ha}^{-1} \mathrm{P}$ followed by $75 \mathrm{~kg} \mathrm{P}$ $\mathrm{ha}^{-1}\left(9.6 \mathrm{mg} \mathrm{kg}^{-1}\right)$ whereas less $\mathrm{P}$ content $\left(5.9 \mathrm{mg} \mathrm{kg}^{-1}\right)$ was noted with $50 \mathrm{~kg} \mathrm{P} \mathrm{ha}^{-1}$. In case of maize plot, highest $\mathrm{P}$ content $\left(15.8 \mathrm{mg} \mathrm{kg}^{-1}\right)$ was recorded with $100 \mathrm{~kg} \mathrm{P}^{-1}$ then by $75 \mathrm{~kg} \mathrm{P} \mathrm{ha}^{-1}(14.7 \mathrm{mg}$ $\left.\mathrm{kg}^{-1}\right)$ whereas lowest $\mathrm{P}$ content $\left(10.9 \mathrm{mg} \mathrm{kg}^{-1}\right)$ was recorded with $50 \mathrm{~kg} \mathrm{P} \mathrm{ha}^{-1}$. This might be due to the release of organically bound $\mathrm{P}$ in organic sources released by soil micro-organism and might have exerted significant effect on soil P content (Jones and Healey, 2010; Joseph et al., 2010; Karhu et al., 2011 and Khan et al., 2013). Application of beneficial microbes feeds on soil organic matter and release nutrients to maintain crop growth and make available plants nutrients for roots uptake (Khattak and Muhammad, 2008; Karhu and Shah, 2011). The year effect was found significant for both crops soil and high $\mathrm{P}$ concentration in soybean and maize soil was recorded in year 2 as compared to year 1 . The possible reason might be the accumulation of the both year's inputs. Another reason might be due the degradation of peach organic sources by the action of beneficial microbes and may have released the bound and assimilated P. The Interactions between OS x BM, OS x PL and OS x BM x PL was found significant (Fig. 1). Phosphorus content in soil was increased with biochar amendments along with PSB inoculation whereas biochar and $\mathrm{P}$ at the rate of $100 \mathrm{~kg} \mathrm{~h}^{-1}$ showed maximum P content in soil. These results were supported by Mukherjee and Zimmerman, (2013) who stated that soil P content increased with inorganic P application (Laird et al., 2010; Lentz and Ippolito, 2012; Maes and Verbist, 2012). The interactive effect of OS x BM x PL (Fig. 2, Fig. 12, Fig. 13, Fig. 14,) increased P content in soybean as well as in maize plots (Fig. 2, ) with biochar amendments along with PSB and 
$\mathrm{P}$ at the rate of $100 \mathrm{~kg} \mathrm{ha}^{-1}$. It has been reported that soil $\mathrm{P}$ content were significantly increased by the combined application of biochar and PSB (Major et al., 2010; McLaughlin et al., 2011). The higher the organic matter the less fertilizer should be need because more plant nutrients are released in the soil. High organic matter soils can help keep a crop growing and healthier longer during prolonged dry periods because of the higher water holding capacity. Soil application of biochar can improve soil nutrient retention and availability to plants due to high CEC and similar mechanism could be responsible for increase in soil P content and crop productivity (Nelson et al., 2011). Soil organic matter serves many important functions. The higher the organic matter the better the soil is. Organic matter comes from plant residue and roots that have been broken down and decomposed by soil microorganisms. Only about 10 percent of organic material is converted to stable organic matter, so it takes a lot of plant residue, roots and time to increase the amount in the soil significantly (Norton et al., 2012). This is especially true in warmer and drier climates where the amount of material that can be grown is limited and the organic matter is mineralized quicker by the microorganisms.

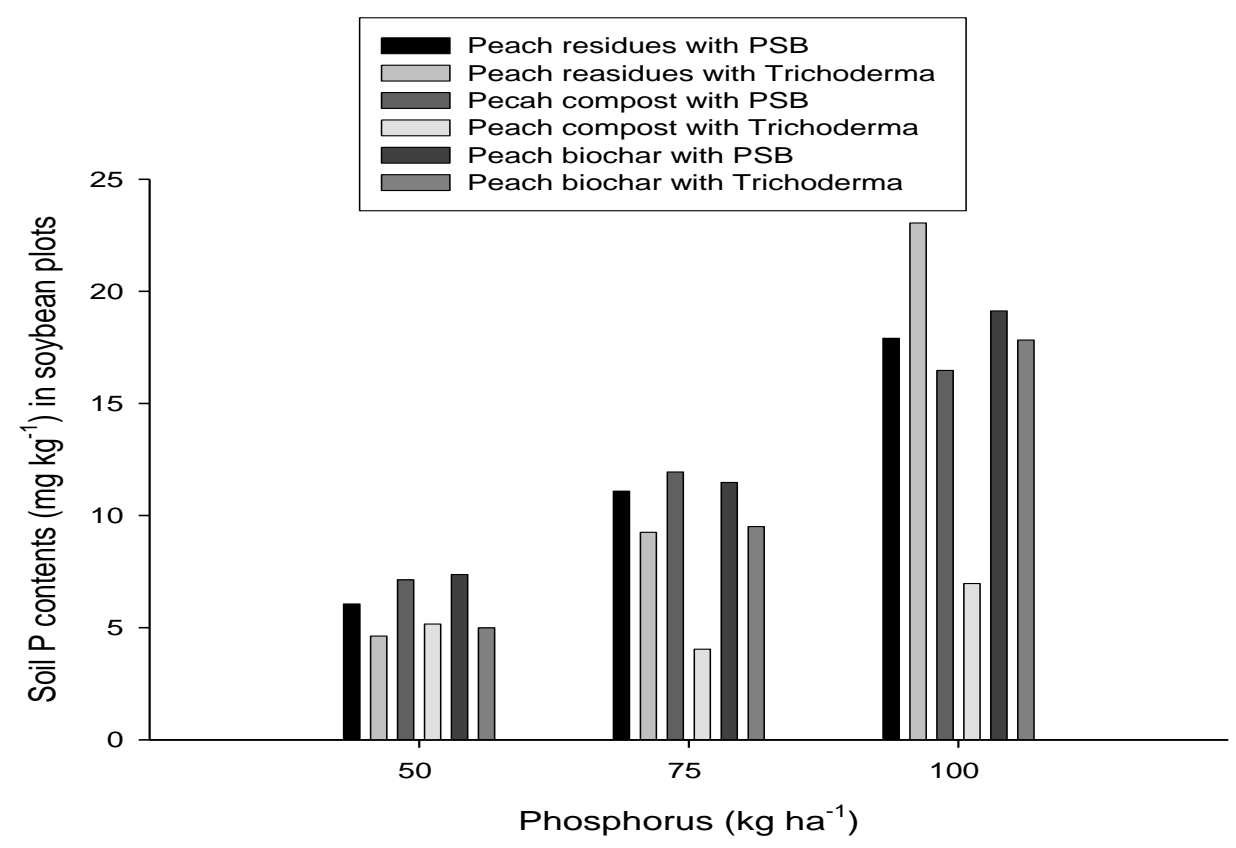

Figure 1. Interaction among organic sources, phosphorus level and beneficial microbes for soil phosphorus content of soybean plot. 
Table 2. Soil phosphorus and phosphorus use efficiency (PUE \%) of soybean and maize as influenced by organic sources, phosphorus and beneficial microbe's application.

\begin{tabular}{|c|c|c|c|c|}
\hline \multirow{3}{*}{ Treatments } & \multicolumn{4}{|c|}{ Soybean vs Maize } \\
\hline & \multicolumn{2}{|c|}{ Soybean } & \multicolumn{2}{|c|}{ Maize } \\
\hline & Soil P & PUE (\%) & Soil P & PUE (\%) \\
\hline \multicolumn{5}{|l|}{ Organic Sources (OS) } \\
\hline Peach Residues & $12.0 \mathrm{a}$ & $12.9 \mathrm{c}$ & $11.6 \mathrm{c}$ & $25.6 \mathrm{c}$ \\
\hline Peach Compost & $8.6 b$ & $19.3 b$ & $14.1 \mathrm{~b}$ & $28.1 \mathrm{ab}$ \\
\hline Peach Biochar & $11.7 \mathrm{a}$ & $25.6 \mathrm{a}$ & $15.8 \mathrm{a}$ & $28.4 \mathrm{a}$ \\
\hline LSD $_{0.05}$ & 1.89 & 2.57 & 1.49 & 0.40 \\
\hline \multicolumn{5}{|l|}{ Beneficial Microbes (BM) } \\
\hline PSB & $12.1 \mathrm{a}$ & $16.9 \mathrm{~b}$ & $15.1 \mathrm{a}$ & $26.9 b$ \\
\hline Trichoderma & $9.5 b$ & $21.7 \mathrm{a}$ & $12.5 \mathrm{~b}$ & $27.8 \mathrm{a}$ \\
\hline Sig Level & $* *$ & $* * *$ & $* * *$ & $* * *$ \\
\hline \multicolumn{5}{|l|}{ Phosphorus (kg ha-1) } \\
\hline 50 & $5.9 \mathrm{c}$ & $14.7 \mathrm{~b}$ & $10.9 \mathrm{~b}$ & $33.5 \mathrm{a}$ \\
\hline 75 & $9.6 b$ & $22.2 \mathrm{a}$ & $14.7 \mathrm{a}$ & $26.6 b$ \\
\hline 100 & $16.9 \mathrm{a}$ & $21.0 \mathrm{a}$ & $15.8 \mathrm{a}$ & $22.0 \mathrm{c}$ \\
\hline LSD $_{0.05}$ & 1.89 & 2.57 & 1.49 & 0.40 \\
\hline \multicolumn{5}{|l|}{ Years } \\
\hline 2016 & $9.1 b$ & 20.7 & $12.3 b$ & 27.4 \\
\hline 2017 & $12.4 \mathrm{a}$ & 17.9 & $15.3 \mathrm{a}$ & 27.4 \\
\hline Sig Level & $*$ & $\mathrm{~ns}$ & $* *$ & $\mathrm{~ns}$ \\
\hline \multicolumn{5}{|l|}{ Planned Mean Comparison } \\
\hline Control & $5.3 b$ & 0.0 & $5.4 \mathrm{~b}$ & 0.0 \\
\hline Rest & $10.8 \mathrm{a}$ & $12.1 \mathrm{a}$ & $13.8 \mathrm{a}$ & 27.4 \\
\hline Sig Level & $* *$ & $* * *$ & $* * *$ & $* * *$ \\
\hline Interaction & Sig Level & Sig Level & Sig Level & Sig Level \\
\hline OS x BM & $* *$ & ns & $* *$ & $\mathrm{~ns}$ \\
\hline OS x PL & $* *$ & $*$ & $*$ & $* * *$ \\
\hline BM x PL & ns & $* *$ & ns & ns \\
\hline OS x BM x PL & $* *$ & $\mathrm{~ns}$ & $*$ & $\mathrm{~ns}$ \\
\hline $\mathrm{Y} \times \mathrm{OS}$ & $* *$ & ns & $*$ & $* * *$ \\
\hline Y x BM & ns & ns & ns & $\mathrm{ns}$ \\
\hline Y x P & ns & ns & ns & $* * *$ \\
\hline Y x OS x BM & ns & ns & ns & $* *$ \\
\hline Y x OS x PL & $* *$ & ns & ns & ns \\
\hline Y x BM x PL & ns & ns & ns & ns \\
\hline Y x OS x BM x PL & $\mathrm{ns}$ & ns & ns & ns \\
\hline Y x Control Vs Rest & $\mathrm{ns}$ & $\mathrm{ns}$ & ns & $\mathrm{ns}$ \\
\hline
\end{tabular}

Mean of the similar groups, followed by similar letters are non-significantly different from each other at $(\mathrm{P}<0.05) 5 \%$ level of probability using LSD test.

Whereas ${ }^{* *}=p<0.001,{ }^{* *}=p<0.01$ and $^{*}=p<0.05$ though ns, stand for non-significant. 


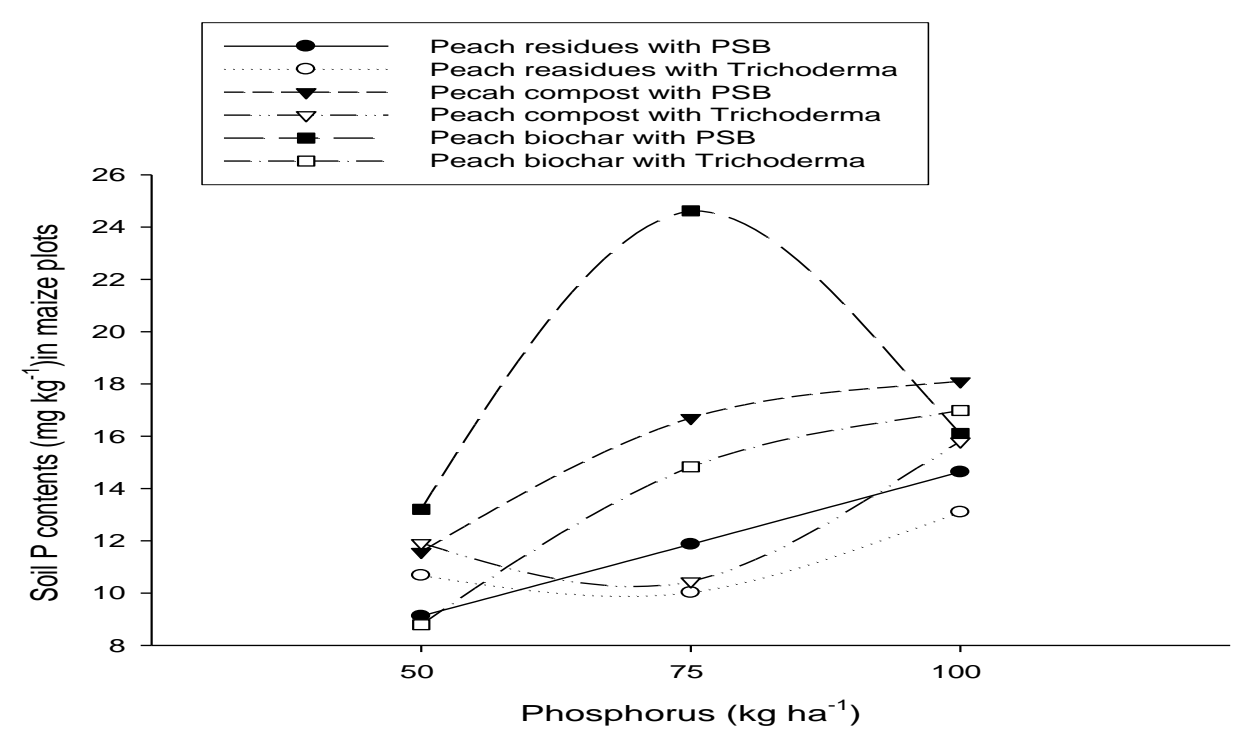

Figure 2. Interaction among organic sources, phosphorus level and beneficial microbes for soil phosphorus content of maize plot.

\section{Phosphorus use efficiency of soybean and maize crops}

Organic sources, beneficial microbes and phosphorus levels had significant effect on $P$ use efficiency while the year effect was non-significant for both crops (Table 2). Phosphorus use efficiency of soybean was maximum with biochar $(25.6 \%)$, followed by compost amendment $(19.3 \%)$ while lowest PUE was recorded under peach residues (12.9\%) incorporation. In case of maize PUE was greater $(28.4 \%)$ than soybean with biochar followed by at par compost treated plots (28.1\%). Lowest PUE was noted under peach residues (25.6\%) in both crops. Our results indicated that maize crop was $P$ use efficient than soybean. It has been stated by many researcher that nutrients use efficiency and $\mathrm{P}$ uptake influence by many factors (e.g. soil structure, rooting patterns, nitrogen $(\mathrm{N})$ applied, soil moisture etc.) and thus increase or decrease P use efficiency (Yuan and Xu, 2011; Ye et al., 2014). P use efficiency can be discussed and assessed in several ways (Xiang et al., 2012; Imran et al., 2018). Beneficial microbe's application increased PUE. Soil application of Trichoderma (21.7\%) improved PUE in soybean and maize (27.8\%) than seed inoculation with PSB (16.9\% soybean \& $26.9 \%$ maize). The reason could be microbial action on peach organic sources and adsorb P contents in soil to enhance availability of P. Imran et al. (2018) reported that soil organic matter (biochar, compost and residues) provide $\mathrm{P}$ to crop plant, or plants obtained $\mathrm{P}$ from previous fertilizer accumulated, i.e. residual P. Small amount of the $\mathrm{P}$ taken up by a crop comes directly from the fertilizer applied to it, the remainder must come from the soil P reserves (Khattak and Muhammad, 2008; Laird et al., 2010; Lentz and Ippolito, 2012).

Phosphorus application increased PUE in both crops and highest PUE in soybean (22.2\%) was recorded with $75 \mathrm{~kg} \mathrm{P} \mathrm{Pa}^{-1}$ whereas in maize crop highest PUE (33.5\%) was noted with $50 \mathrm{~kg} \mathrm{P} \mathrm{ha-1}$. Mujeeb et al. (2010) reported that lower rates of $P$ fertilization resulted in increased efficiency than the higher rates of P fertilization. Maes and Verbist, (2012) concluded that nutrients use efficiency was increased where the fertilizer use was relatively low and crop demand was high.

The interactions (OS $x$ PL, BM $x$ PL, Y $x$ OS, Y $x$ OS $\times$ BM $x$ PL) (Fig. $7 \&$ 8) for PUE in soybean and in maize (OS $\times \mathrm{PL}, \mathrm{Y} \times \mathrm{OS}, \mathrm{Y} \times \mathrm{P}$ and $\mathrm{Y} \times \mathrm{OS} \times \mathrm{BM}$ ) (Fig. 10) were found significant. Biochar and compost along with $50 \mathrm{~kg} \mathrm{P}^{-1}{ }^{-1}$ increased PUE in soybean. Interaction between BM x PL indicated that soil application of Trichoderma along with $\mathrm{P}$ at the rate of $75 \mathrm{~kg} \mathrm{ha}^{-1}$ increased PUE in soybean as compared to other treatments. In maize crop interaction between OS x PL revealed that PUE increased with biochar and compost along with $\mathrm{P}$ at the rate of $75 \mathrm{~kg} \mathrm{ha}^{-1}$ while interaction between $\mathrm{Y} \times \mathrm{OS}$ had highest PUE in year 1 along with biochar application although in year $2 \mathrm{P}$ application enhanced PUE. 
Phosphorus agronomic efficiency (PAE) of soybean and maize crops

Application of all the organic sources (biochar, compost and peach residues) phosphorus levels and beneficial microbes significantly increased PAE in both crops (Table 3). Application of compost and biochar gave at par high value PAE in soybean $\left(15.8 \& 15.7 \mathrm{~kg} \mathrm{~kg}^{-1}\right)$ and maize $(27.2 \&$ $26.5 \mathrm{~kg} \mathrm{~kg}^{-1}$ ) respectively. Lowest PAE in both crops were recorded under peach dry based residues treated plots. Organic matter is a reservoir of nutrients that are mineralized by microorganisms and released in the soil that plants can use. For each percent of organic matter in the soil about 25 pounds of nitrogen, 5 pounds of $\mathrm{P}_{2} \mathrm{O}_{5}$, and 3 pounds of sulfur become plant available annually. In high organic matter level soils this can lead to significant fertilizer savings. Among beneficial microbes, soil applied Trichoderma proved best with higher PAE in soybean $\left(15.9 \mathrm{~kg} \mathrm{~kg}^{-1}\right)$ and in maize $(25.8 \mathrm{~kg} \mathrm{~kg}$ ${ }^{1}$ ) as compared to seed inoculated PSB. Maize crop was efficient in PAE than soybean and produced more grain per $\mathrm{kg} P$ applied. In case of $\mathrm{P}$ application to soybean $\left(16.1 \mathrm{~kg} \mathrm{~kg}^{-1}\right)$ and maize crop highest PAE $\left(25.9 \mathrm{~kg} \mathrm{~kg}^{-1}\right)$ was noted with $75 \mathrm{~kg} \mathrm{P} \mathrm{ha}^{-1}$. Our results revealed that soybean and maize produced maximum grain per $\mathrm{kg} P$ applied. Interactive effect of BM $\times$ PL (Fig. 3 \& 4) also resulted in increased $\mathrm{P}$ uptake by soybean with soil application of Trichoderma and $\mathrm{P}$ at the rate of $75 \mathrm{~kg} \mathrm{P} \mathrm{ha}^{-1}$. Integration of biochar amendments and $\mathrm{P}$ at the rate of $75 \mathrm{~kg} \mathrm{ha}^{-1}$ showed significantly more PAE of applied P. Effectiveness of inorganic P fertilizers was increased and PAE was improved with the addition of organic sources. Xiang et al. (2012) and Fageria et al. (2013) confirmed that small amount of the P taken up by a crop comes directly from the fertilizer applied to it, the remainder must come from the soil P reserves. Imran et al. (2018) reported that soil organic matter provide P to crop plant, or plants obtained P from previous fertilization accumulated, i.e. residual P. It has been stated by many researcher that nutrients use efficiency and P uptake influence by many factors (e.g. soil structure, rooting patterns, nitrogen $(\mathrm{N})$ applied, soil moisture etc.) and thus increase or decrease $\mathrm{P}$ use efficiency (Nelson et al., 2011; Norton et al., 2012). P use efficiency can be discussed and assessed in several ways according to the definition used (Major et al., 2010; McLaughlin et al., 2011). Singh et al. (2010) illustrated that the amount of the P taken up by a crop comes directly from the fertilizer applied to it the remainder must come from the soil $\mathrm{P}$ reserves naturally present in the soil. Imran et al. (2018) observed that application of fertilizer P in soil increased P use efficiency, P agronomic efficiency. In maize crop interactive effect between OS x PL (Fig. 9) indicated that integration of biochar amendments and $\mathrm{P}$ at the rate of $75 \mathrm{~kg} \mathrm{ha}^{-1}$ showed significantly more AE of applied P. our findings are in relation with Mujeeb et al. (2010) who stated that aapplication of all the organic and inorganic amendments significantly $(\mathrm{P}<0.05)$ increased the agronomic efficiency of $\mathrm{P}$ applied to the soils. Xiang et al. (2012) and Fageria et al. (2013) confirmed that $P$ fertilizer use efficiency increased with application of BM. Machado, (2011) and Maes and Verbist, (2012) observed that application of fertilizer $\mathrm{P}$ in soil increased $\mathrm{P}$ use efficiency and $\mathrm{P}$ agronomic efficiency.

Table 3. Phosphorus agronomic efficiency (PAE kg kg-1) and partial factor productivity of soybean and maize as influenced by organic sources, phosphorus and beneficial microbe's application.

\begin{tabular}{ccccc}
\hline \multirow{2}{*}{ Treatments } & \multicolumn{4}{c}{ Soybean } \\
\cline { 2 - 4 } & PAE (\%) & PFPp & PAE (\%) & PFPp \\
\cline { 2 - 5 } & & & & Maize \\
\hline Organic Sources (OS) & $11.8 \mathrm{~b}$ & $25.2 \mathrm{~b}$ & $20.8 \mathrm{~b}$ & $58.8 \mathrm{~b}$ \\
\hline Peach Residues & $15.8 \mathrm{a}$ & $29.2 \mathrm{a}$ & $26.5 \mathrm{a}$ & $64.5 \mathrm{a}$ \\
Peach Compost & $15.7 \mathrm{a}$ & $29.1 \mathrm{a}$ & $27.2 \mathrm{a}$ & $65.2 \mathrm{a}$ \\
Peach Biochar & 1.01 & 0.97 & 0.99 & 0.92 \\
\hline LSD 0.05 & $13.0 \mathrm{~b}$ & $26.4 \mathrm{~b}$ & $23.8 \mathrm{~b}$ & $62 \mathrm{~b}$ \\
\hline Beneficial Microbes (BM) & $15.9 \mathrm{a}$ & $29.3 \mathrm{a}$ & $25.8 \mathrm{a}$ & $64 \mathrm{a}$ \\
\hline PSB & $* * *$ & $* * *$ & $* * *$ \\
\hline Trichoderma & \multicolumn{3}{c}{} \\
\hline Sig Level & & & \\
\hline
\end{tabular}




\begin{tabular}{|c|c|c|c|c|}
\hline 50 & $12.8 \mathrm{c}$ & $31.4 \mathrm{a}$ & $24.4 \mathrm{~b}$ & $77.1 \mathrm{a}$ \\
\hline 75 & $16.1 \mathrm{a}$ & $28.5 b$ & $25.9 \mathrm{a}$ & $61.0 \mathrm{~b}$ \\
\hline 100 & $14.4 \mathrm{~b}$ & $23.6 \mathrm{c}$ & $24.1 \mathrm{bc}$ & $50.4 \mathrm{c}$ \\
\hline LSD $_{0.05}$ & 1.01 & 0.97 & 0.99 & 0.92 \\
\hline \multicolumn{5}{|l|}{ Years } \\
\hline 2016 & 14.7 & $25.8 b$ & 25.1 & 62.9 \\
\hline 2017 & 14.1 & $29.8 \mathrm{a}$ & 24.5 & 62.9 \\
\hline Sig Level & ns & $* *$ & ns & ns \\
\hline \multicolumn{5}{|l|}{ Planned Mean Comparison } \\
\hline Control & 0.0 & 0.0 & 0.0 & 0.0 \\
\hline Rest & $14.4 \mathrm{a}$ & $27.8 \mathrm{a}$ & $24.8 \mathrm{a}$ & $62.9 \mathrm{a}$ \\
\hline Sig Level & $* * *$ & $* * *$ & $* * *$ & $* * *$ \\
\hline Interaction & Sig Level & Sig Level & Sig Level & Sig Level \\
\hline OS x BM & $\mathrm{ns}$ & $\mathrm{ns}$ & $\mathrm{ns}$ & $\mathrm{ns}$ \\
\hline OS x PL & $* * *$ & $* * *$ & $* *$ & $* * *$ \\
\hline BM x PL & $* * *$ & $* * *$ & ns & ns \\
\hline OS x BM x PL & $\mathrm{ns}$ & ns & ns & ns \\
\hline $\mathrm{Y} \times \mathrm{OS}$ & $* * *$ & $* * *$ & $* * *$ & $* * *$ \\
\hline Y x BM & ns & ns & ns & $\mathrm{ns}$ \\
\hline Y x P & $*$ & ns & $* * *$ & $* * *$ \\
\hline Y x OS x BM & ns & ns & $*$ & $* *$ \\
\hline Y x OS x PL & ns & ns & ns & ns \\
\hline Y x BM x PL & ns & ns & ns & ns \\
\hline Y x OS x BM x PL & $* *$ & $* *$ & ns & ns \\
\hline Y x Control Vs Rest & ns & $*$ & ns & ns \\
\hline
\end{tabular}

Mean of the similar groups, followed by similar letters are non-significantly different from each other at $(\mathrm{P}<0.05) 5 \%$ level of probability using LSD test.

Whereas $^{* *}=p<0.001,^{* *}=p<0.01$ and $^{*}=p<0.05$ though ns, stand for non-significant.

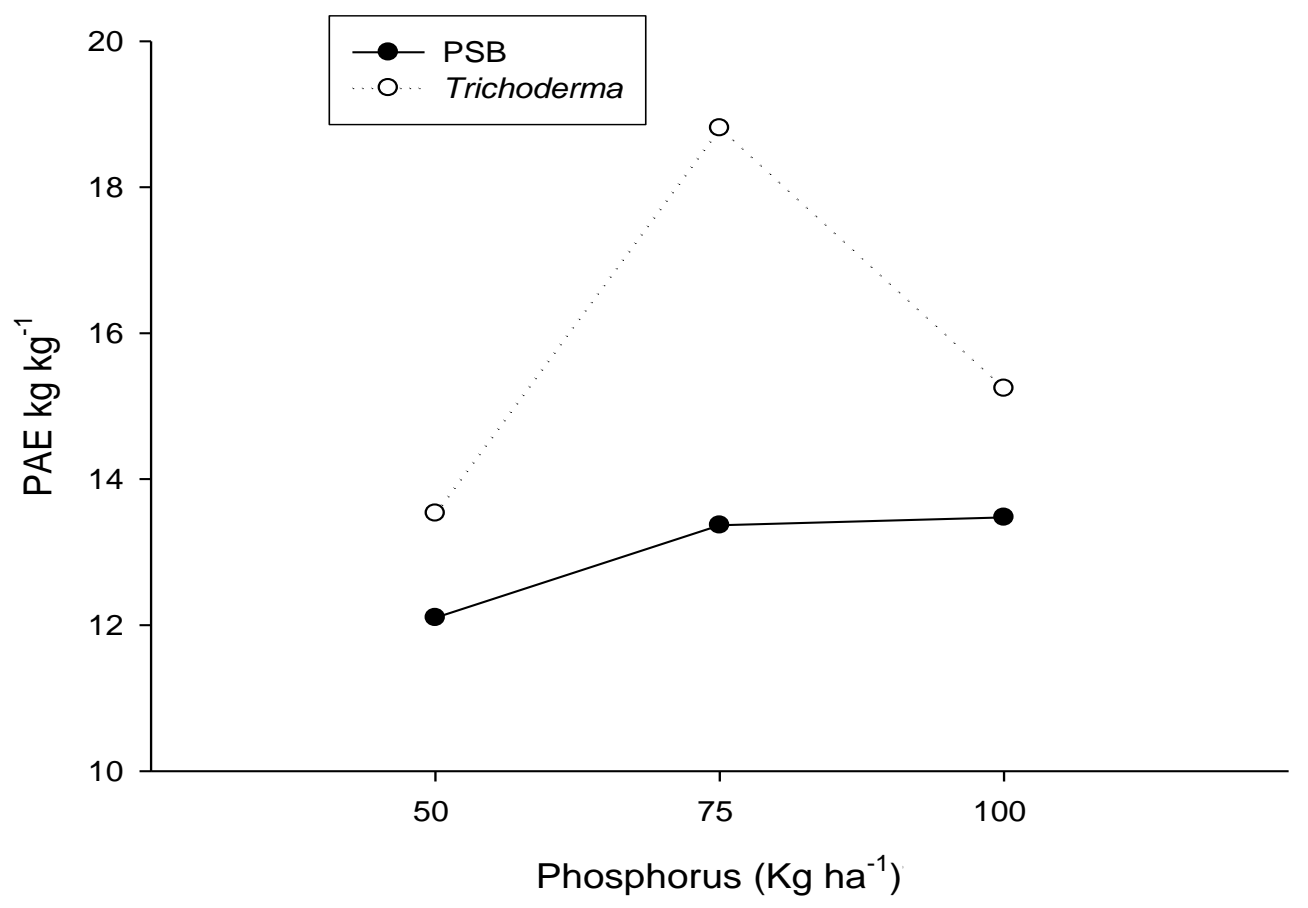

Figure 3. Interaction between phosphorus level and beneficial microbes for phosphorus agronomic efficiency of soybean. 


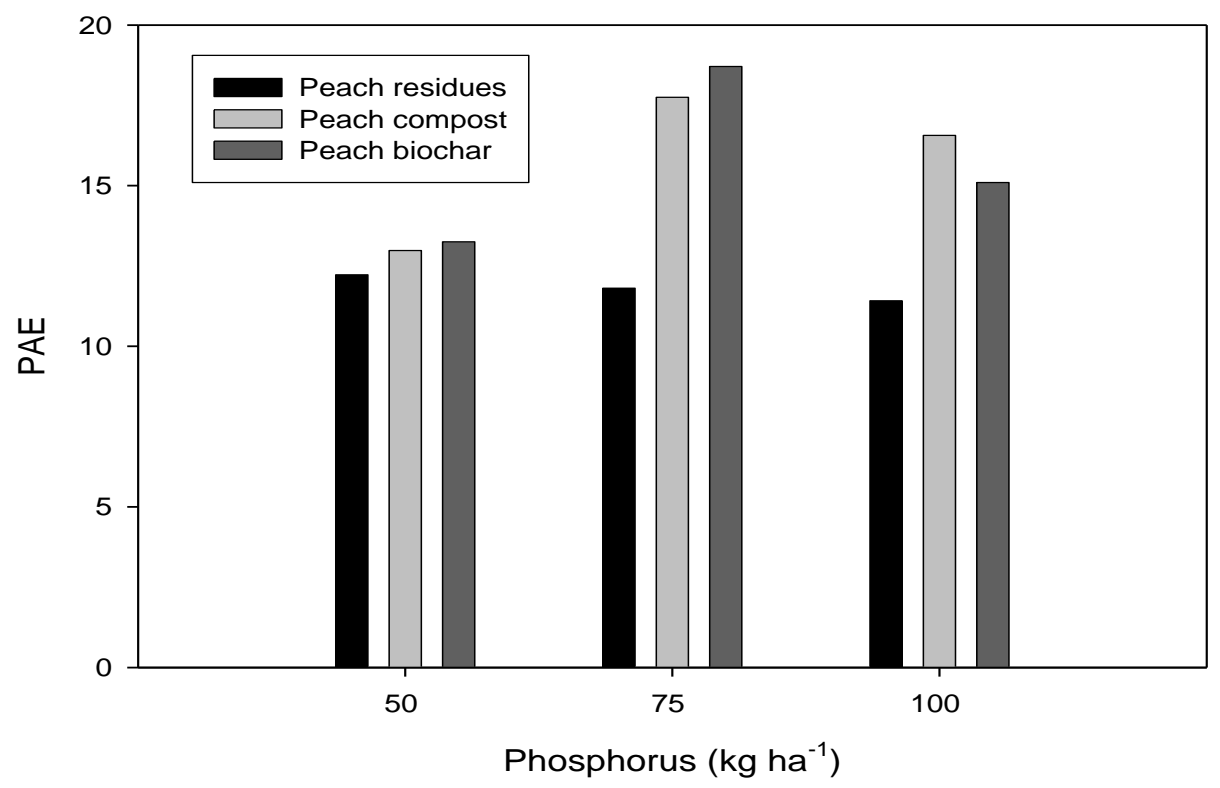

Figure 4. Interaction between peach organic sources and phosphorus levels for phosphorus agronomic efficiency of soybean.

Phosphorus partial factor productivity (PFPp) of soybean and maize crops

Partial factor productivity of $\mathrm{P}$ has positive response towards organic sources (biochar, compost and peach residues), phosphorus levels and beneficial microbes (Table 3). Application of compost and biochar in both crops gave at par high PFPp and noted 29.2 \& $29.1 \mathrm{~kg}^{\text {grains }} \mathrm{kg}^{-1} \mathrm{P}$ in soybean whereas $65 \mathrm{~kg}_{\text {grains }} \mathrm{kg}^{-1} \mathrm{P}$ in maize. Beneficial microbes application play major role in nutrients solubilisation and availability. Nutrients uptake and use efficiency directly related to microbial action. Soil application of Trichoderma was found more profound and produced $29.3 \mathrm{~kg}$ grains $\mathrm{kg}^{-1} \mathrm{P}$ in soybean as compared to seed inoculation with PSB $\left(26.4 \mathrm{~kg}\right.$ grains $\left.\mathrm{kg}^{-1} \mathrm{P}\right)$. Similarly in maize crop Trichoderma produced more grain $\left(64 \mathrm{~kg}_{\text {grains }} \mathrm{kg}^{-1} \mathrm{P}\right)$ than PSB $\left(62 \mathrm{~kg}\right.$ grains $\left.\mathrm{kg}^{-1} \mathrm{P}\right)$. In case of $\mathrm{P}$ application, highest value in soybean $\left(31.4 \mathrm{~kg}\right.$ grains $\left.\mathrm{kg}^{-1} \mathrm{P}\right)$ and in maize $(77 \mathrm{~kg}$ grains $\mathrm{kg}^{-1} \mathrm{P}$ ) for PFPp and was noted with $50 \mathrm{~kg} \mathrm{ha}^{-1}$. The year effect was also found significant for both crops and high PFPp $\left(29.8 \mathrm{~kg}_{\text {grains }} \mathrm{kg}^{-1} \mathrm{P}\right)$ was recorded in year 2 than year $1(25.8 \mathrm{~kg}$ grains kg-1 $\mathrm{P})$ in soybean and maize. Interactive effect between OS x PL and BM x PL (Fig. 5 \& 6) was significant and showed that integration of biochar amendments and $\mathrm{P}$ at the rate of $75 \mathrm{~kg} \mathrm{ha}^{-1}$ showed more PFPp in soybean. Interactive effect of BM $\times$ PL (Fig. 11) also resulted in increased PFPp with inoculation of Trichoderma and $\mathrm{P}$ at the rate of $75 \mathrm{~kg} \mathrm{P} \mathrm{ha}^{-1}$. McLaughlin et al. (2011) indicated that $\mathrm{P}$ fertilization increase P use efficiency and partial factor productivity. Rose et al. (2012) divulged that PFP is measure of efficiency that includes production per unit of nutrient applied. Yuan and $\mathrm{Xu}$, (2011) reported that PFP indicates how productive a crop in comparison to its nutrient input is. Richardson et al. (2011) clarified that with the lower testing soil, P use efficiency by the difference method ranged from 24 to $43 \%$ and decreased with the amount of P applied. Xiang et al., (2012) revealed that grain yield was increased with total $P$ removed in the grain and straw with increased $P$ levels. 


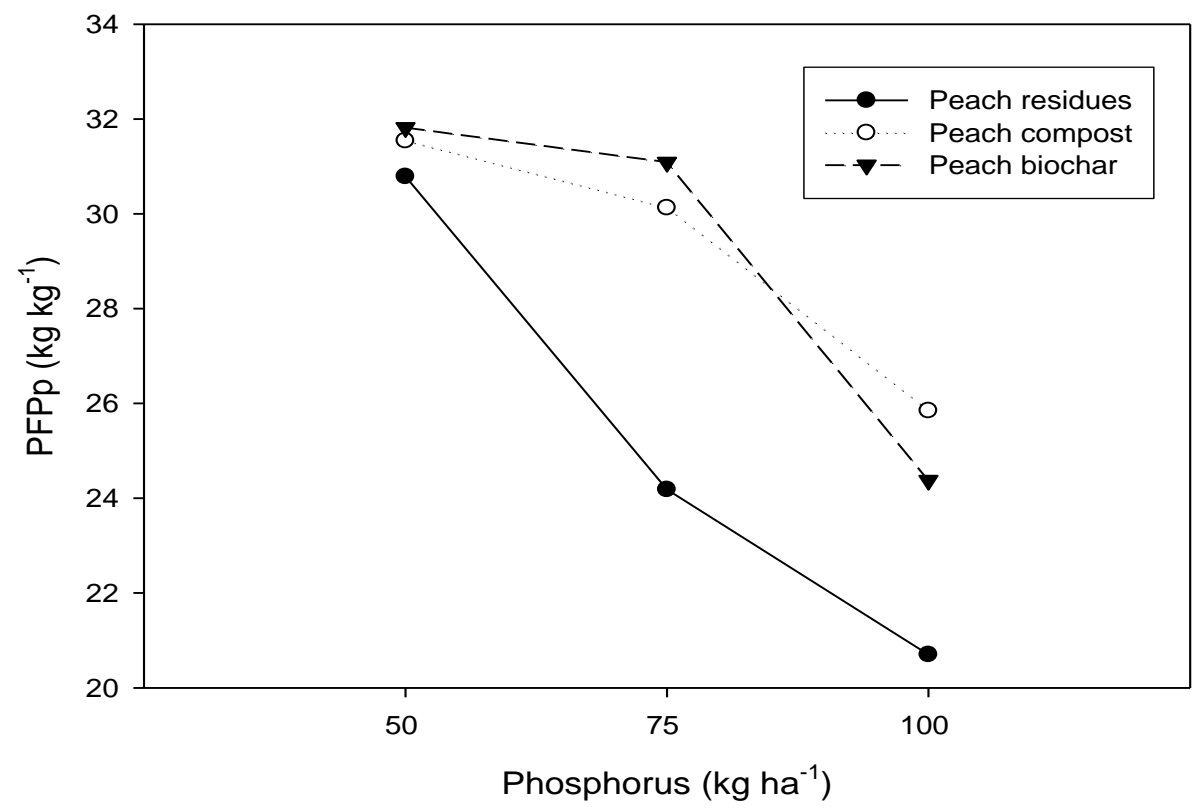

Figure 5. Interaction between phosphorus levels and peach organic sources for partial factor productivity of phosphorus in soybean.

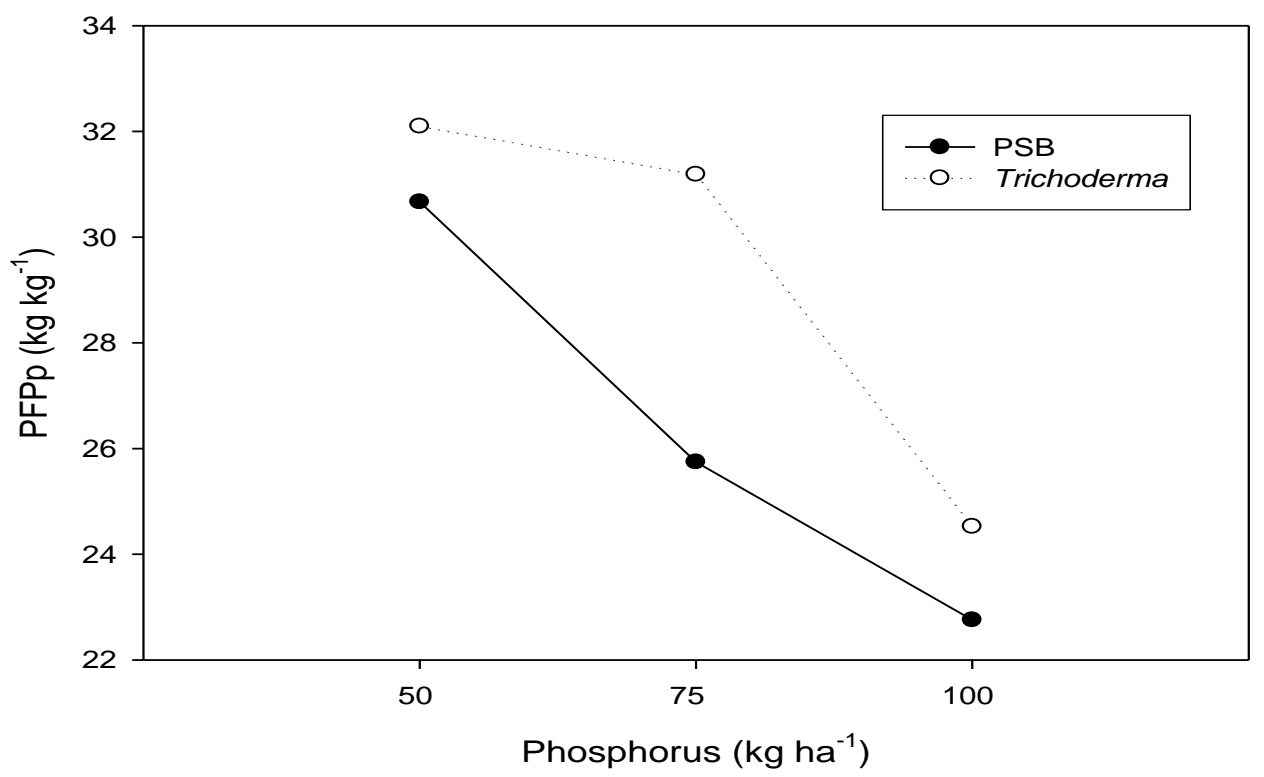

Figure 6. Interaction between phosphorus levels and beneficial microbes for partial factor productivity of phosphorus in soybean. 


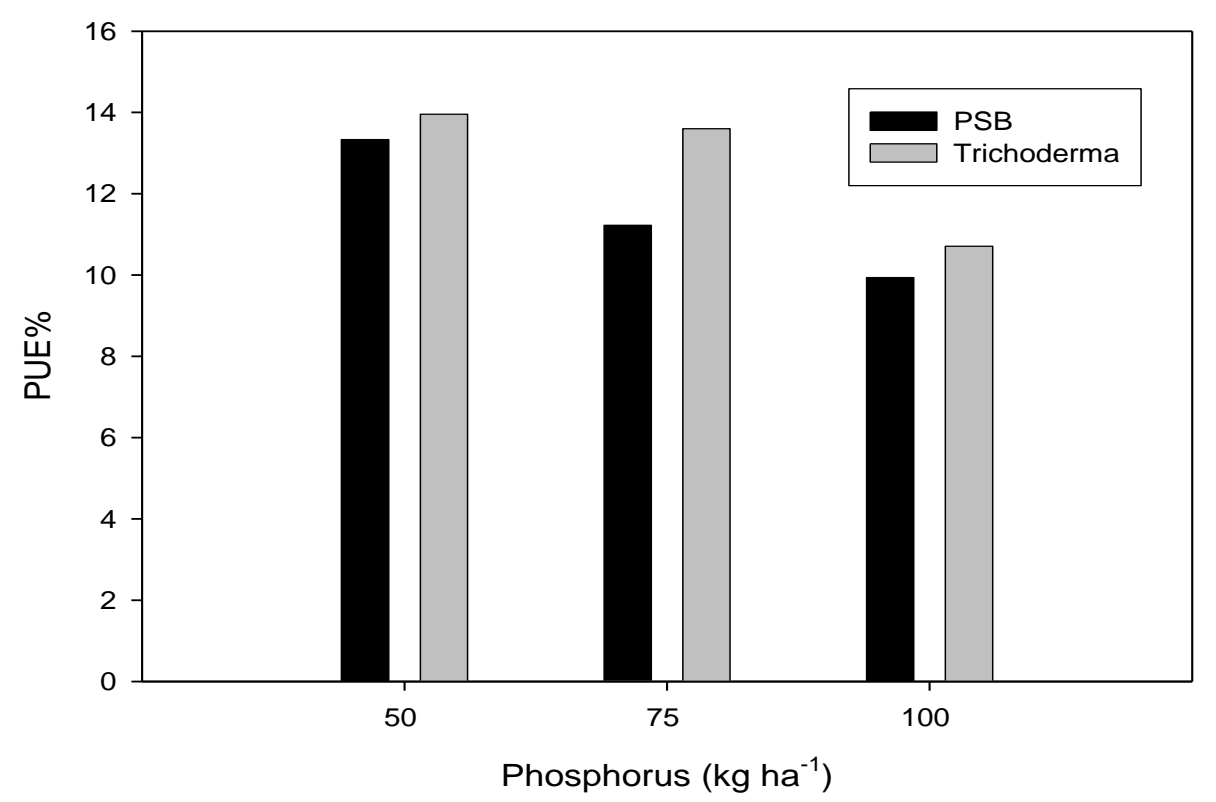

Figure 7. Interaction between phosphorus levels and beneficial microbes for phosphorus use efficiency of soybean.

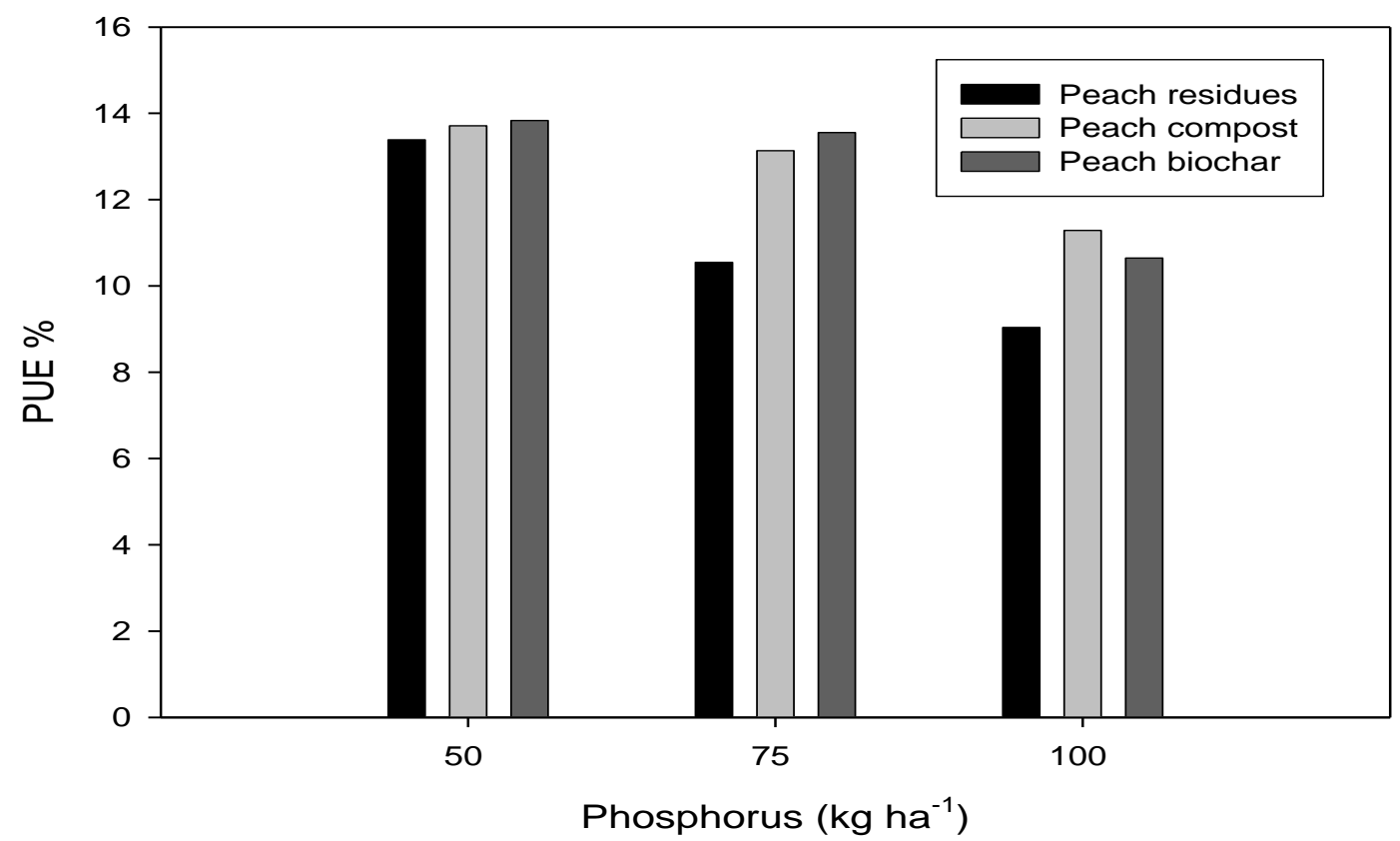

Figure 8. Interaction between phosphorus levels and peach organic sources for phosphorus use efficiency of soybean. 


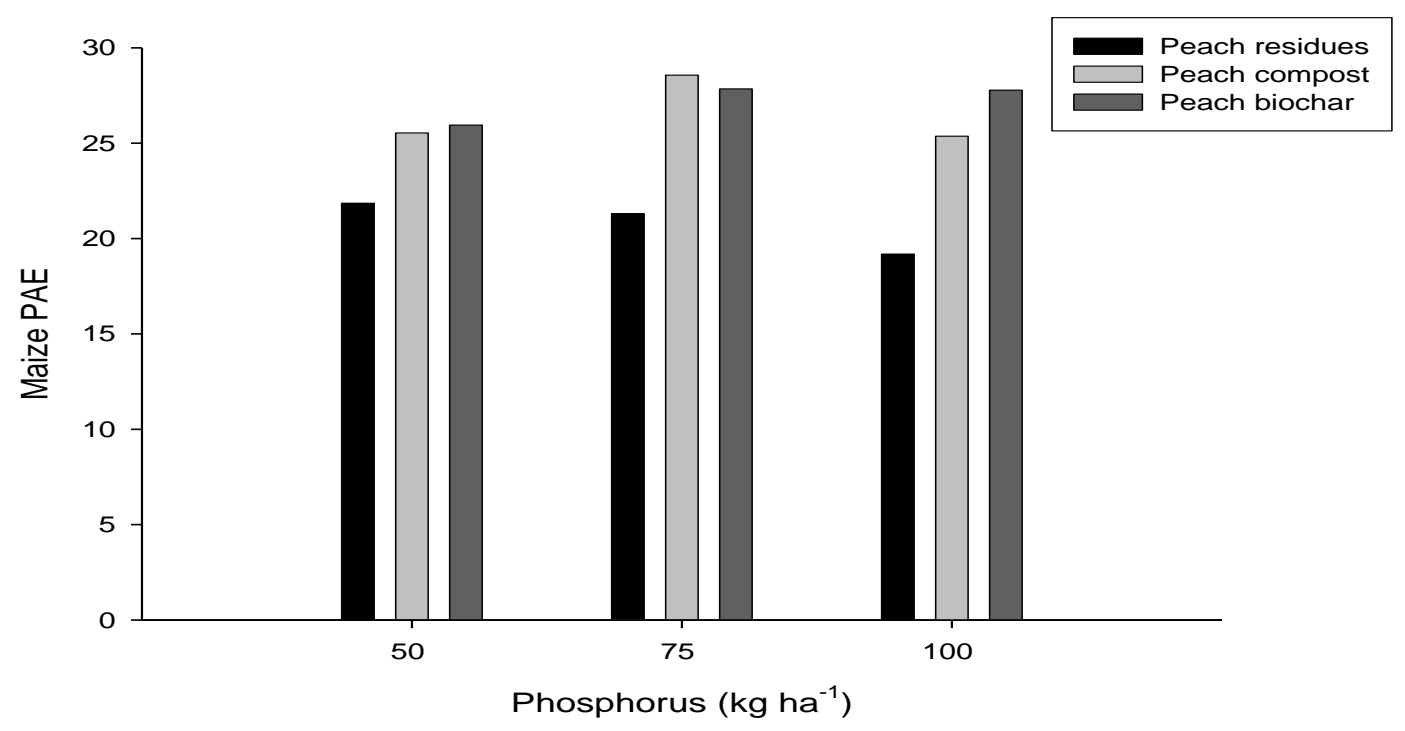

Figure 9. Interaction between phosphorus levels and peach organic sources for phosphorus agronomic efficiency of maize.

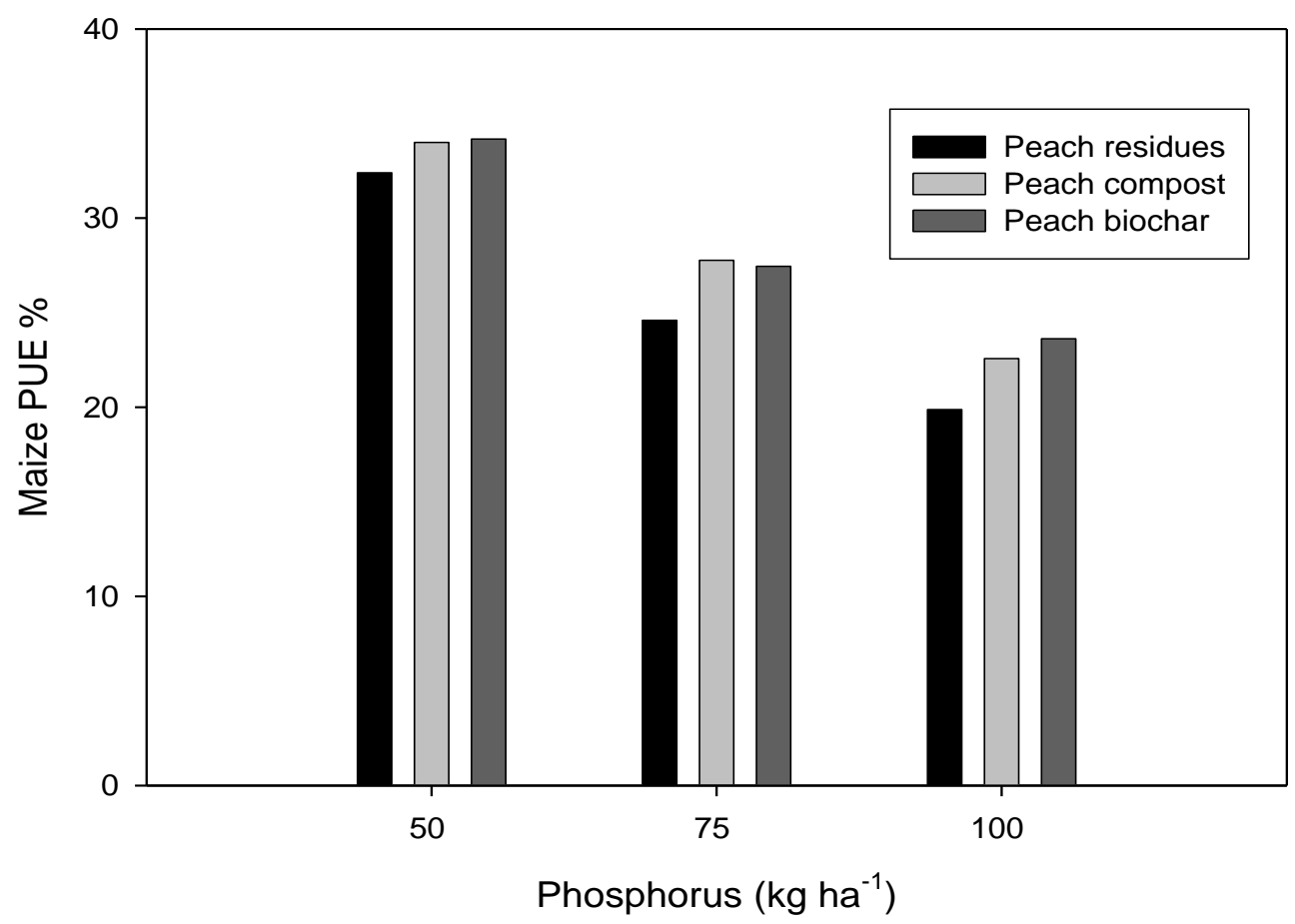

Figure 10. Interaction between phosphorus levels and peach organic sources for phosphorus use efficiency of maize. 


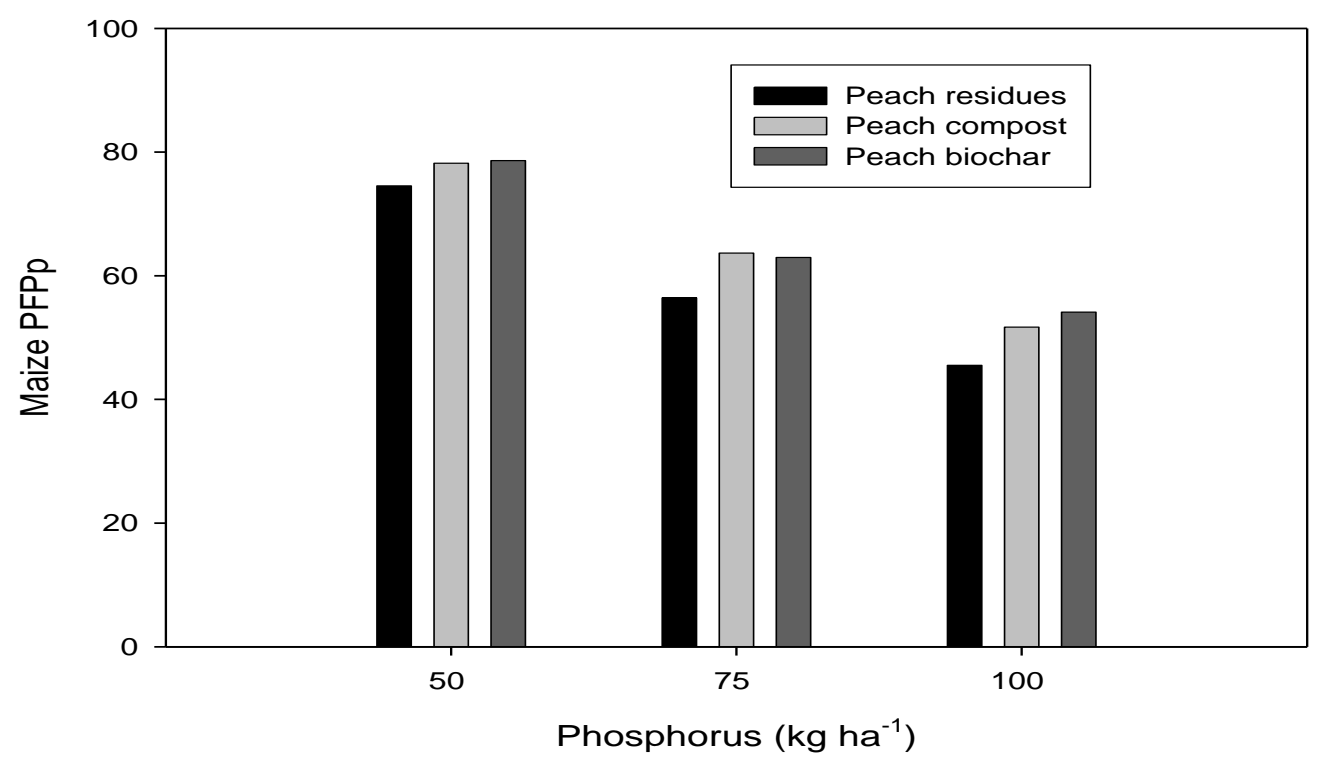

Figure 11. Interaction between phosphorus levels and peach organic sources for phosphorus partial factor productivity of maize.

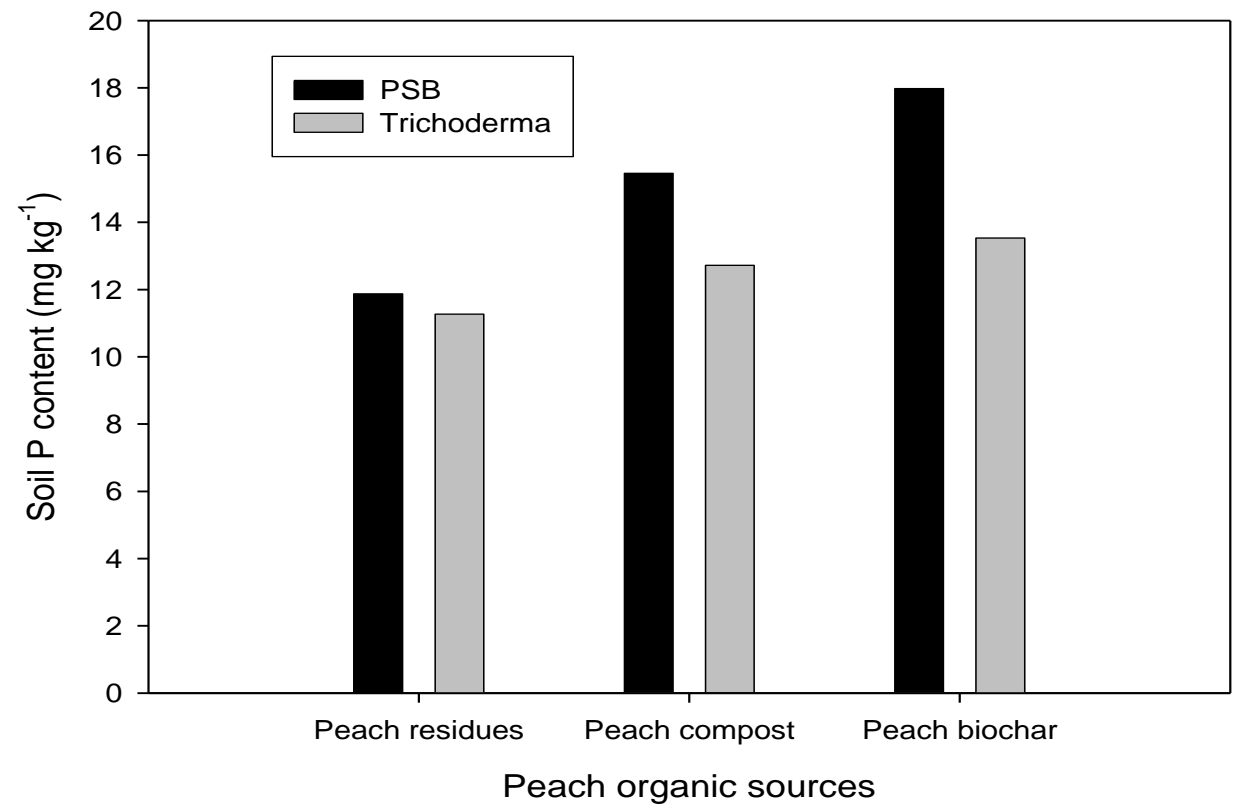

Figure 12. Interaction between peach organic sources and beneficial microbes for soil phosphorus content of maize plot. 


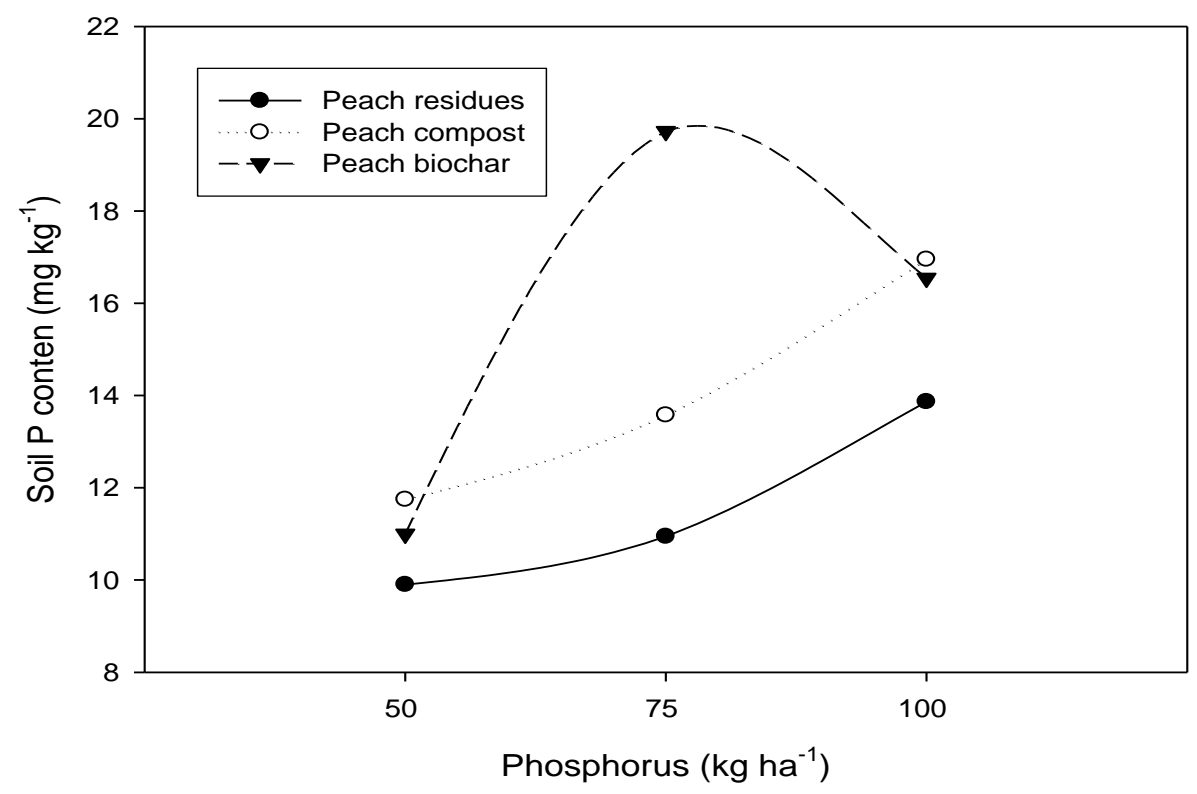

Figure 13. Interaction between phosphorus and peach organic sources for soil phosphorus content of maize plot.

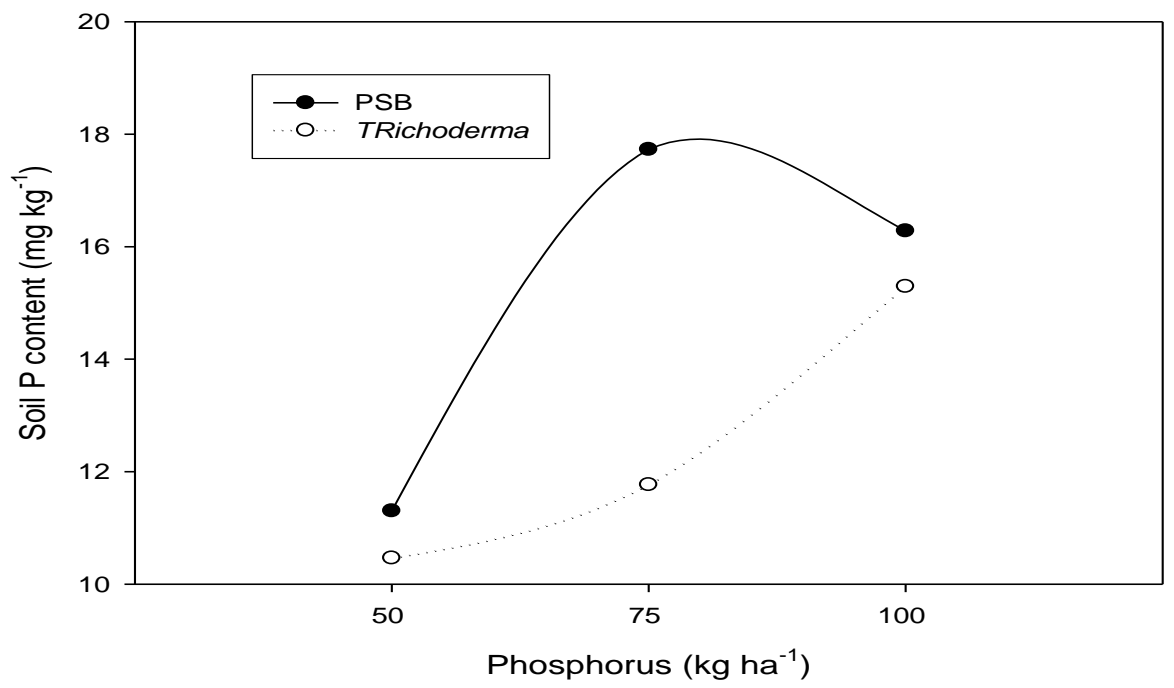

Figure 14. Interaction between phosphorus and beneficial microbes for soil phosphorus content of maize plot. 


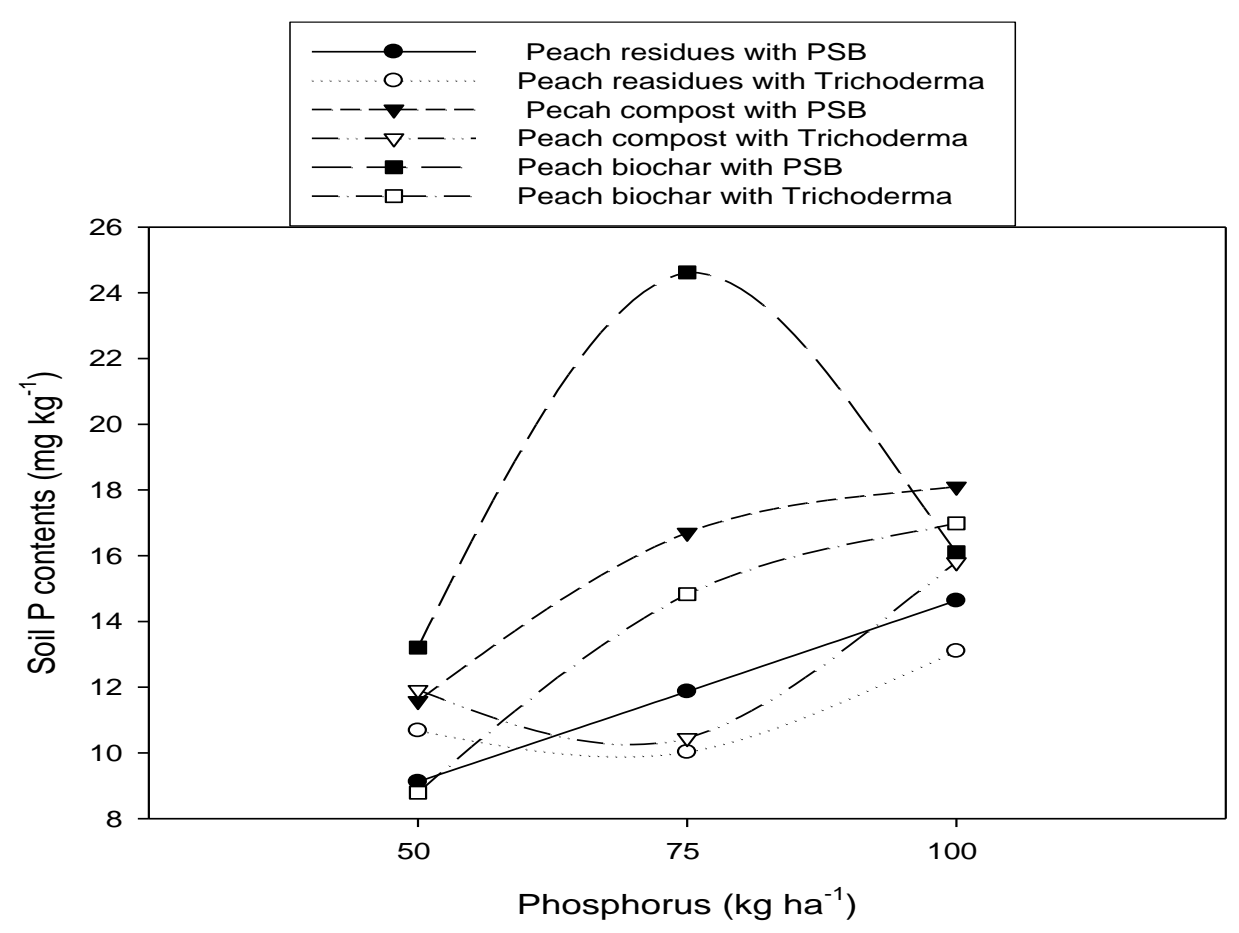

Figure 15. Interaction among peach organic sources, phosphorus and beneficial microbes for soil phosphorus content of maize plot.

\section{Conclusion}

It was concluded that soil $\mathrm{P}$ contents in both soybean and maize plots were increased with application of peach organic sources along with beneficial microbes and $100 \mathrm{~kg} \mathrm{P} \mathrm{ha-1}$ as compared to control plot. Application of peach biochar along with Trichoderma and $75 \mathrm{~kg} \mathrm{P}^{-1} \mathrm{a}^{-1}$ increased PUE, PAE and PFPp.

\section{References}

1. Arif, M., Muhammad. I, Muhammad. R, Kawsar. A, Kamran .S, Izhar. UH and Shah. F. 2017. Biochar improves phosphorus use efficiency of organic-inorganic fertilizers, maize-wheat productivity and soil quality in a low fertility alkaline soil. Field Crops Research (214) : 25-37.

2. Bourne, M. 1986. Overview of post-harvest problems in fruit. and vegetable. In: Post-harvest Food Losses in Fruits and Vegetables, Bourne, B., Z. Yilt and F.W. Liu. (eds.), Nat. Acad. Press, Washington, D.C. pp. 1-16.

3. Fageria, N. K., A. Moreira \& A. B. dos Santos. 2013. Phosphorus uptake and use efficiency in field crops, journal of plant nutrition, 36:13, 2013-2022, DOI: 10.1080/01904167.2013.816728.

4. Gourley, C. J. P, D.L. Allan and M. P. Resselle. 1993. Defining phosphorus use efficiency. Plant and soil. 155(156) 289-292.

5. Imran. 2018. Organic Matter Amendments Improve Soil Health, Productivity and Profitability of Maize and Soybean. Ann Rev Resear. 1(3): 555564.

6. Imran, Amanullah, A. Bari and R. Ali. 2018. Peach sources, phosphorus and beneficial microbes enhance productivity of soybean. Soy. Res. 16(2): 39-48.

7. Imran, Nasar Jamal, Ashfaq Alam And Asad Ali Khan. 2017. Grain Yield, Yield Attributes Of Wheat And Soil Physio-Chemical Charicteristics Influenced By Biochar, Compost And Inorganic Fertilizer Application. Agri Res \& Tech: Open Access J. DOI: 10.19080/ARTOAJ.2017.10.555795

8. Iqbal A, Amanullah, Ali A, Iqbal M, Ikramullah and Imran. 2017. Integrated use of phosphorus and organic matter improve fodder yield of moth bean (Vigna aconitifolia (Jacq.) under irrigated and dryland conditions of Pakistan. Journal of AgriSearch 4(1): 10-15. 
9. Jones, D.L., J.R. Healey. 2010. Organic amendments for remediation: putting waste to good use. Elements 6: 369-374.

10. Joseph, S.D., M. Camps-Arbestain, Y. Lin, P. Munroe, C.H. Chia, J. Hook, L. van Zwieten, S. Kimber, A. Cowie, B.P. Singh, J. Lehmann, N. Foidl, R.J. Smernik, J.E. Amonette. 2010. An investigation into the reactions of biochar in soil. Aust. J. Soil Res. 48: 501-515.

11. Karhu, K., T. Mattila, I.M. Bergstro, K. Regina. 2011. Biochar addition to agricultural soil increased CH4 uptake and water holding capacity-results from a short-term pilot field study. Agr. Ecosyst. Environ. 140: 309-313.

12. Khan, H. Z., M. Nadeem, S. Iqbal, N. Akbar and A. Iqbal. 2013. Response of spring maize (Zea mays L.) to integrated nitrogen management. Crop Environ. 4: 6-10.

13. Khan, M., T. Rahim, M. Naeem, M.K. Shah, Y. Bakhtiar and M. Tahir. 2008. Post harvest economic losses in peach produce in district Swat. Sarhad J. Agric. 24(4): 705-711.

14. Khan, M.A., S.A.A. Shah. 2011. Food insecurity in Pakistan: causes and policy response. J. Agric. Environ. Eth. 24: 493-509.

15. Khattak, R.A. and D. Muhammad. 2008. Increasing crop production through humic acid in rainfed and salt-affected soils in Kohat division. Final Technical Progress Rep. ALP-PARC, Islamabad Proj. Deptt. Soil and Environ. Sci. The Univ. of Agric. Peshawar, Pakistan.

16. Laird, D. A., P. Fleming, D.D. Davis, R. Horton, B. Wang, D.L. Karlen. 2010 Impact of biochar amendments on the quality of a typical Midwestern agricultural soil. Geoderma 158: 443-449.

17. Lentz, R.D., J.A. Ippolito. 2012. Biochar and manure affect calcareous soil and corn silage nutrient concentrations and uptake. J. Environ. Qual. 41: 1033-1043.

18. Machado, S. 2011. Soil organic carbon dynamics in the Pendleton long-term experiments: Implications for biofuel production in Pacific Northwest. Agron. J. 103:253-260. doi:10.2134/agronj2010.0205s

19. Maes, W.H., B. Verbist. 2012. Increasing the sustainability of household cooking in developing countries: policy implications. Renew. Sustain. Energy Rev. 16: 4204-4221.

20. Major, J., M. Rondon, D. Molina, S.J. Riha, J. Lehmann. 2010. Maize yield and nutrition during 4 years after biochar application to a Colombian savanna oxisol. Plant Soil 333: 117-128.

21. McLaughlin, M.J., T.M. McBeath, R. Smernik, S.P. Stacey, B. Ajiboye, C. Guppy. 2011. The chemical nature of $P$ accumulation in agricultural soils-implications for fertilizer management and design: an Australian perspective. Plant Soil 349: 69-87.

22. Mengel, K. and E.A. Kirkby. 2001. Principles of Plant Nutrition. $5^{\text {th }}$ Ed., Kluwer Academic Publishers, London.

23. Mujeeb, F., Rahmatulla, J. Akhtar and R. Ahmad. 2010. Integration of organic and inorganic P sources for improving P use efficiency in different soils. Soil \& Environ. 29(2): 122-127.

24. Mukherjee, A., A.R. Zimmerman. 2013. Organic carbon and nutrient release from a range of laboratoryproduced biochars and biochar-soil mixtures. Chemosphere 142: 106-113.

25. Nelson, N. O., S.C. Agudelo, W. Yuan, J. Gan. 2011. Nitrogen and phosphorus availability in biocharamended soils. Soil Sci. 176: 218-226.

26. Norton, R.M., P. Howie, C. Walker. 2012. Soil test values and nutrient balances from a long term fertilizer experiment. In: Yunusa, I. (Ed.), Capturing Opportunities and Overcoming Obstacles in Australian Agronomy. Proceedings of 16th Australian Agronomy Conference 2012, October 1418, 2012, Armidale, New South Wales.

27. Rose TJ, J. Pariasca-Tanaka, MT. Rose, A. Mori, M. Wissuwa. 2012. Seeds of doubt: re-assessing the impact of grain P content on seedling vigor. Journal of Plant Nutrition and Soil Science 175: 799-804.

28. Singh, B., B.P. Singh, A.L. Cowie. 2010. Characterisation and evaluation of biochars for their application as a soil amendment. Soil Res. 48: 516-525.

29. Steel, R.G.D. and J.H. Terrie. 1996. Principles and procedures of statistics: A biometrical approach. 2 nd ed. McGraw-Hill, New York.

30. U.S. Salinity Laboratory Staff. 1954. Diagnosis and Improvement of Saline and Alkali Soils. USDA Handbook No. 60, Washington, DC, USA.

31. Xiang, D.B., T.W. Yong, W.Y. Yang, Y. Wan, W.Z. Gong, L. Cui and T. Lei. 2012. Effect of phosphorus and potassium nutrition on growth and yield of soybean in relay strip intercropping system. Sci. Res. Essays. 7(3): 342-351. 
32. Ye Y, Liang X, Y. Chen, L. Li, Y. Ji, C. Zhu. 2014. Carbon, nitrogen and phos- phorus accumulation and partitioning, and C:N:P stoichiometry in late- season rice under different water and nitrogen managements. PLoS One 9: e101776.

33. Yuan, J. H., R.K. Xu. 2011. The amelioration effects of low tempera- ture biochar generated from nine crop residues on an acidic Ultisol. Soil Use Manage. 27: 110-115. 